\title{
The Rise and Fall of the Pyramid Schemes in Albania
}

\author{
CHRIS JARVIS*
}

What lessons can be drawn from the unprecedented growth and spectacular collapse of financial pyramid schemes in Albania? This paper discusses the origins of the pyramid schemes and the way the authorities handled them. It also analyzes the economic effects of the pyramid schemes, concluding that despite the descent into anarchy triggered by the schemes' collapse, their direct effects on the economy are difficult to specify and appear to have been limited. Finally, the paper argues that prevention of pyramid schemes is better than cure and that governments and international financial institutions should be vigilant in clamping down on frauds. [JEL E65, G14, G18]

his paper tells the story of the Albanian pyramid scheme crisis of 1996-97, analyzes its causes and consequences, and attempts to draw some lessons from it. The pyramid scheme phenomenon in Albania is important because its scale relative to the size of the economy was unprecedented, and because the political and social consequences of the collapse of the pyramid schemes were profound. At their peak, the nominal value of the pyramid schemes' liabilities amounted to almost half of the country's GDP. When the schemes collapsed, there was uncontained rioting, the government fell, and the country descended into anarchy and a near civil war in which some 2,000 people were killed. This paper explores the causes of the rise of the pyramid schemes and addresses the question of what could have been done to prevent it. It also examines the handling of the crisis. The

\footnotetext{
*Chris Jarvis is a Senior Economist in the IMF's Policy Development and Review Department. He thanks Jacques Artus, Bob Corker, Juha Kähkönen, Sanjay Kalra, Tim Lane, Alfredo Leone, Ranjit Teja, and other colleagues at the IMF for helpful comments and insights, as well as Marie Ricasa and Gordana Rodic for secretarial support and Luzmaria Monasi and Jane Keneshea for valuable research assistance.
} 
paper then discusses the economic effects of the pyramid scheme phenomenon and concludes that despite the tremendous political effects, the economic effects have been surprisingly limited. Finally, it suggests lessons that can be drawn from the crisis by other governments and by the international financial institutions.

\section{Rise of Pyramid Schemes}

\section{Economic Background to Emergence of Pyramid Schemes}

Albania started the transition process from central planning as the most isolated, undeveloped, and poor country in Europe. Albania had for centuries been largely unknown and inaccessible, ${ }^{1}$ and from 1945 to 1985 its isolation was compounded by the rigid dictatorship of Enver Hoxha. Communism in Albania was founded on complete reliance on central planning, the elimination of almost all forms of private property, and the idealization of national self-reliance as a guiding tenet of economic policy. In practice, this led to a virtual cutting off of the country from outside influences and information. ${ }^{2}$ The result was that when transition eventually began, in 1991, the country had been reduced to desperate poverty and the vast bulk of the population was completely unfamiliar with market institutions or practices.

Albania's progress during the early transition years was impressive. Like all countries starting transition, Albania faced initial shocks: output fell by nearly half between 1989 and 1992, and inflation rose to triple digits. However, during 1993-95 GDP growth averaged close to 10 percent while inflation fell to single digits and external imbalances were reduced sharply (see Table 1). The impressive macroeconomic performance reflected in large part wholesale dismantling of controls; early privatization of agriculture, retail trade, and small and mediumsized enterprises; and improved financial discipline at the budgetary and state enterprise levels.

However, by early 1996 it was clear that many problems had not been solved, and that others were reemerging. Structural reform had stalled, especially in the critical area of banking. The approach of parliamentary elections in May 1996 led the government to indulge in preelection wage increases and to put off introduction of a VAT, with the result that the budget deficit and inflation began to rise again. Nor did things improve after the elections, which were won decisively by the ruling Democratic Party but were widely believed to have been rigged. From this point on, the government's political authority was fragile, and its will to take difficult decisions limited. This was to have significant implications for the unfolding pyramid scheme crisis.

\footnotetext{
${ }^{1}$ In the 1780s Edward Gibbon described Albania as "a country within sight of Italy which is less known than the interior of America." See Davies, 1996, p. 645.

${ }^{2}$ Economic conditions in Albania before transition are described in detail in Blejer and others, 1992. Hoxha's hostility to outside influences is illustrated by his breaking successively with the USSR and China on the grounds that they were too moderate, and, more concretely, by his building of about half a million bunkers-one for every six Albanians_-for defense against foreign invaders.
} 


\section{Problems in the Financial Sector}

One of the most important causes of the growth of the pyramid scheme phenomenon was the inadequacy of the formal financial system. The three state banks that dominated the deposit-taking market (holding over 90 percent of deposits) were not reliable intermediaries of savings, and private banks were slow to emerge and not particularly interested in attracting domestic currency deposits, devoting their attention mostly to trade financing. The problem in the state banks was not low interest rates: to ensure that depositors were offered interest rates that are positive in real terms, the Bank of Albania set minimum interest rates on time deposits, and from mid-1993 onward these were consistently above the prevailing rate of inflation. However, the payments system was seriously inadequate. In September 1996, the average completion time for payment transactions between accounts at different branches of the same state-owned bank was 5-6 days, and the completion time when the transaction involved accounts at different state-owned banks could exceed 15 days. As a result of these problems, and of a general distrust of the banks, the public tended to hold an unusually high proportion of their financial assets in cash (at end-1995 the currency/deposit ratio was 64 percent) and was on the lookout for alternative investment opportunities.

On the lending side, the banks' problems were even worse, leading to the emergence of an informal credit market. Banking supervision and regulation was rudimentary, and this, combined with a culture under which loans from state banks were often regarded by borrowers as not requiring repayment, led to a growing bad loan problem. By the end of 1994, of loans made since June 1992 when the state banks began operations, 27 percent were nonperforming. By the end of 1995, in two of the three state-owned banks, overdue loans accounted for almost half of total outstanding loans. ${ }^{3}$ In response to the banks' poor credit evaluation and loan collection, the Bank of Albania imposed bank-by-bank credit ceilings. These were set at levels that were well below what the banks wanted and insufficient to meet the demands for credit to the private sector at prevailing interest rates. The limitations of the banking system made these measures sensible, indeed necessary, but the result was that businesses increasingly turned for credit to the informal credit market. A survey of over 200 enterprises conducted in late 1996 found that 36 percent of them had used the informal market to fund their investments, compared with 38 percent that had used bank credit (Muço and Salko, 1996).

\section{Informal Credit Market and Pyramid Schemes}

An informal credit market had been flourishing in Albania since the transition began, and it was generally tolerated by the authorities. The informal market consisted partly of foreign exchange dealers (some licensed, some not) and partly of a number of companies taking deposits and making loans. These companies were

\footnotetext{
${ }^{3}$ The banks' poor credit evaluation is epitomized by the state-owned Rural Commercial Bank's making short-term loans to farmers to buy tractors and trucks. At end-1996, the tractor and truck loans still accounted for one-third of the bank's total lending and 80 percent of its bad loans. The bank was liquidated in December 1997.
} 


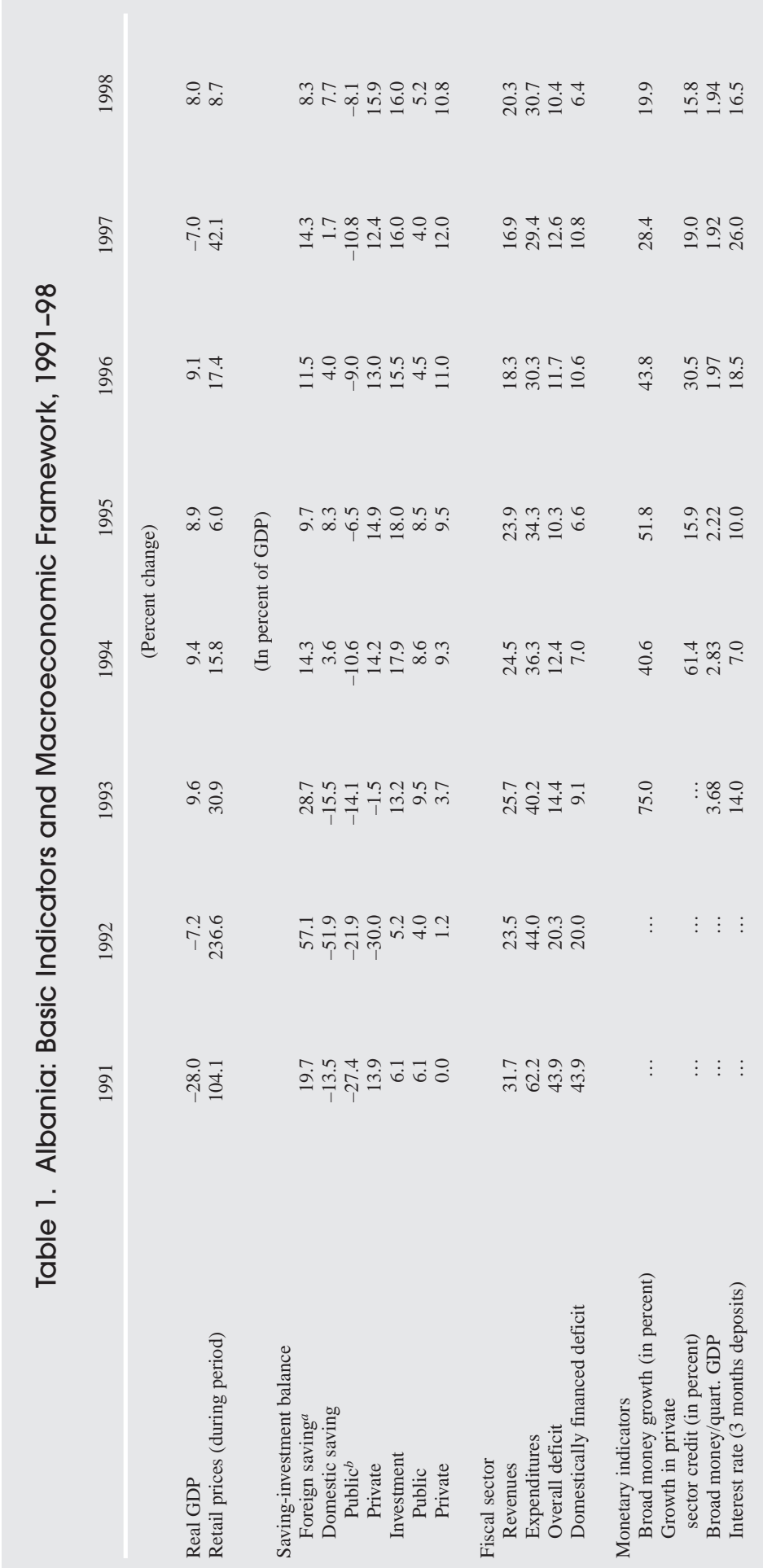




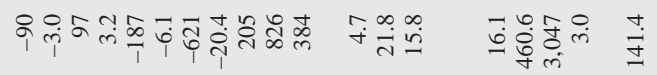

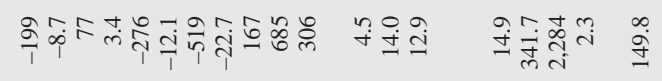

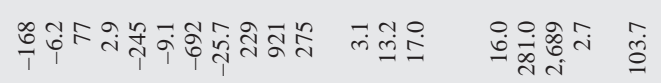
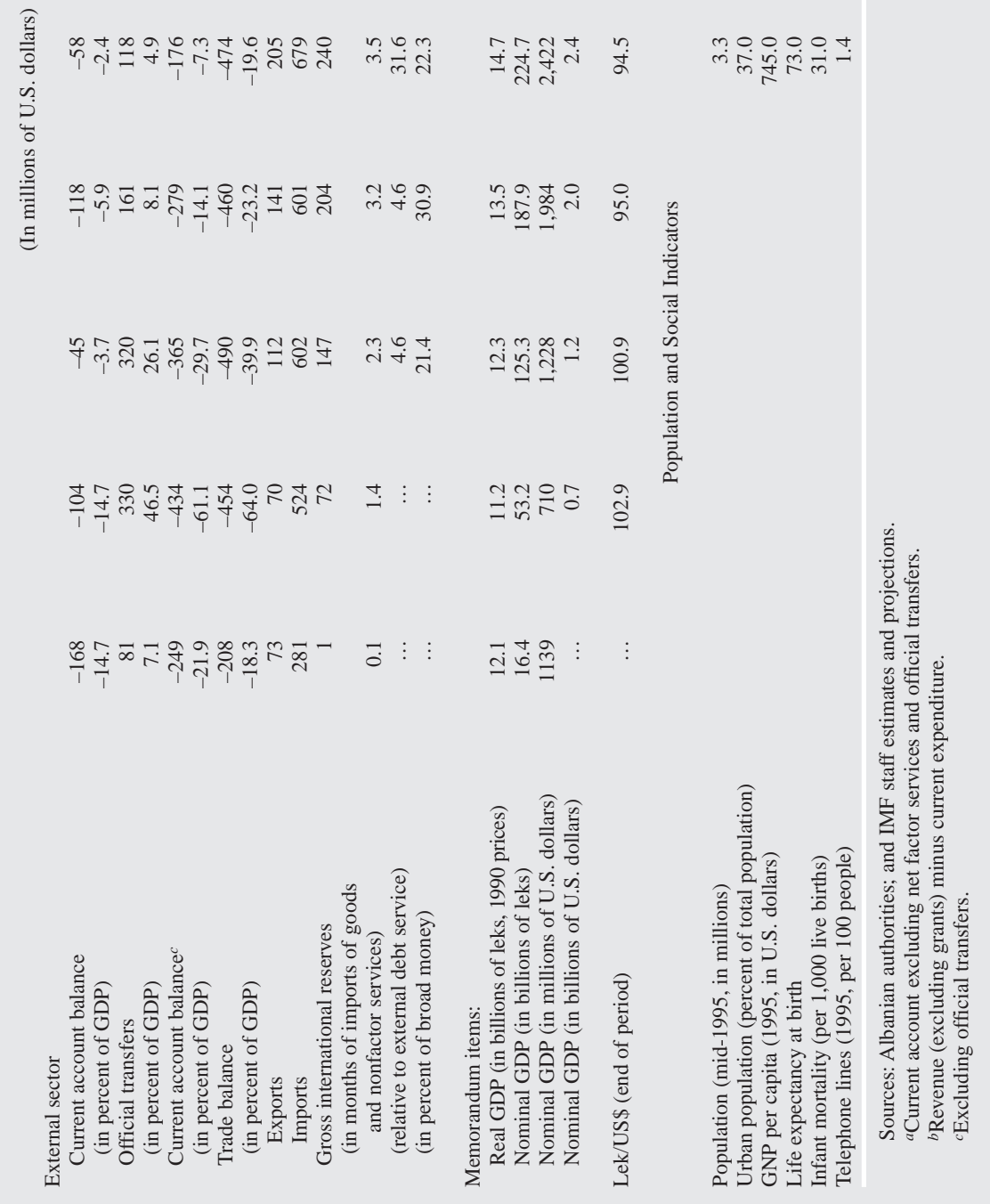
informal and arguably illegal, since they were never licensed to take deposits. They grew out of a credit system based mostly on private loans from migrant workers to friends and family. According to Bank of Albania officials, loans made were generally less than US\$30,000, most companies had fewer than eight loans outstanding, and substantial collateral was required. Informal market lending rates were high: real rates were around 8 percent a month in 1993, although they had fallen to 6 percent a month in the second half of 1995 (Muço and Salko, 1996). There is no record of deposit rates offered by these companies, but these were presumably also high, though somewhat lower than lending rates to allow for a lending spread. Both the authorities and foreign observers, including the IMF, regarded the informal lending companies as benign, and indeed as making an important contribution to growth: given the manifest deficiencies of the formal banks, these companies were probably the best intermediaries for savings in Albania, and the investments they funded were among the most profitable.

However, operating alongside the informal lending companies, and to some extent disguised by them, were a number of companies that also borrowed money at high interest rates but invested on their own account rather than lending funds; it was these that either were or became pyramid schemes. The first and largest of these companies was started in 1991-92 and began collecting money shortly afterward. Up to the end of 1995, these companies offered interest rates of 4-5 percent a month. The use to which they put their funds is uncertain. They engaged in some (usually highly visible) productive investments and are, in some cases, also believed to have used borrowed funds to finance criminal activities: smuggling, illegal emigration, drugs, prostitution, and arms trafficking. Given the nature of these companies, it is not possible to establish whether they were ever solvent, in the sense of earning more from their investments and illegal activities than they were paying to depositors. It is possible that they were pyramid schemes from the day they started business. In any event, if they were not so already, they became pyramid schemes in the course of 1996. (For a definition and description of pyramid schemes see Box 1.)

The distinction between the informal credit market and the pyramid schemes is a vital one, but for a long time it was difficult to see the difference between them. Both the informal credit market and the companies that invested on their own behalf drew resources from domestic savings and from flows of remittances estimated at about US\$300 million a year (about 12 percent of GDP). Both operated on the premise that there were profitable opportunities for investment in small businesses in Albania. The authorities generally shared this view, mostly regarding the borrowing companies as rare success stories among Albanian businesses and discouraging close scrutiny. It was also difficult for outside agencies, including the IMF and the World Bank, to differentiate between the two sets of companies. Neither set of companies were licensed or subject to detailed supervision, and in the case of the companies that invested on their own behalf, their reputation for involvement in criminal activities made information difficult and even dangerous to obtain. ${ }^{4}$ Both the IMF and the World Bank initially treated the companies that

\footnotetext{
${ }^{4}$ In 1995, an IMF consultant posed briefly as a potential investor and was quickly warned that this was not safe.
} 


\section{Box 1. The Dynamics of a Pyramid Scheme}

Pyramid schemes work on the principle that money paid in by later investors is used to pay artificially high returns to earlier investors. There are typically four stages in the life cycle of a pyramid scheme.

(1) Early investors are drawn in by advertising promising high interest rates or huge capital gains after a short period. Most schemes have a gimmick, often based on some real or imagined market inefficiency or loophole in the law.

(2) News of the high returns spreads by word of mouth or advertising, and more people invest. Their payments are used to pay interest and, if necessary, principal to the early investors. More often, though, the early investors will reinvest their principal, and sometimes their interest in the hope of still higher gains. Most people, however, remain skeptical.

(3) With a reputation for solvency based on a good payments record, which overrides doubts about the feasibility of the scheme, many more investors come into the scheme. Some remain skeptical but invest anyway, believing that they can make a quick profit and then get out before the scheme runs into trouble. For a time, the scheme appears successful.

(4) The final stage is the collapse of the scheme. The interest and principal due to the old investors exceeds the money that the scheme is able to attract from new investors. As soon as payments are interrupted, confidence in the scheme evaporates. The investors rush to get their money out, but there is little to be had. What has not been paid to the early investors in interest has usually been used to buy highly visible but often not very valuable assets to make the scheme look prosperous, or has been stolen outright by the operators.

invested on their own account as part of the informal credit market. Thus, an IMF mission to advise on financial sector problems at the end of 1995 focused mostly on the possibilities for improving the formal financial system by integrating the most positive elements of the informal market. While concerns about the possibility of criminals operating in the market were raised, the true nature of the large companies operating at this time, and the scope of their activities, was not picked up by outside observers until mid-1996.

\section{Legal and Governance Problems}

The legal framework available to the authorities to combat the pyramid schemes was inadequate, especially with regard to enforcement. The companies concerned were licensed businesses and claimed to be operating under the Civil Code, which permitted borrowing by companies. However, they were never audited, nor do they appear to have paid profit taxes. In February 1996, a new Law on the Banking System was passed, which stipulated that "no person other than a bank shall accept household deposits, demand deposits, and deposits with an initial maturity of 12 months or less" (Law No. 8075, dated 2/22/96, Article 6). In Article 2 of the same law, "household deposits" were defined as "natural persons' deposits." In the view of the Bank of Albania, the borrowing companies were violating the new law, and the central bank contacted the companies to inform them that they were in the business of deposit taking and required licenses to operate-licenses that the 
Governor of the Bank of Albania had no intention of giving them. However, the Chief Prosecutor took the view that the new law did not apply to the borrowing companies. Nor was he disposed to investigate the companies for fraud. The Ministry of Justice, for its part, refused to give an interpretation. It is arguable that the Bank of Albania should still have used its powers under the Banking System law to close the companies as unlicensed banks. However, given the clear reluctance of other organs of the government to move against them, and the difficulty the Bank would have had in enforcing the law against powerful companies, its failure to do so is understandable.

Indeed, there is strong evidence that the problem was not just a legal one, but one of governance, and that members of the government themselves benefited from and supported the pyramid scheme companies. During the 1996 elections several of the major companies made campaign contributions to the ruling Democratic Party and paid for advertisements on the election posters of Democratic Party candidates. Senior government officials frequently appeared at functions and parties organized by the companies and, in November 1996, even as the pyramid schemes began to crumble, the Prime Minister and Speaker of Parliament accepted medals to celebrate the fifth anniversary of VEFA, the largest company. This tolerance was reflected in the benign neglect of both the Ministry of Justice and the Ministry of Finance, ${ }^{5}$ and in open support of the major companies by the President. Thus, from September 1995 to July 1996 the Governor of the Bank of Albania stood virtually alone in Albania urging investigation and closure of the schemes.

\section{Mania: The Events of 1996}

Two events set the stage for the pyramid scheme mania of late 1996: the suspension of UN sanctions against the Socialist Federal Republic of Yugoslavia (SFRY) in December 1995 and the campaign and outcome of the Albanian parliamentary elections of May 1996. It was an open secret that throughout the period of UN sanctions, oil and many other goods were being smuggled through Albania to the SFRY. Taxes on oil transit trade alone were estimated by IMF staff to amount to 1 percent of GDP. ${ }^{6}$ The involvement of the pyramid scheme companies with the smuggling cannot be proved, but some of the largest companies started up as "trading companies" during the period of sanctions, and they were generally believed to be involved. The suspension of sanctions ended the smuggling trade. One month later, whether by coincidence or because a key source of income had disappeared and they then needed to attract more funds, the borrowing companies raised their interest rates to 6 percent a month. The May elections had a more direct impact. In reaction to uncertainty about the prospects of the ruling Democratic Party in the elections, and also to the entry of new pyramid schemes

\footnotetext{
${ }^{5}$ During discussions between the IMF and the authorities in late 1996, IMF staff suggested that the tax authorities should investigate these companies and close them if they were found to be insolvent. The staff also pointed out that the Russian pyramid scheme, MMM, had initially been prosecuted not for fraud but for tax evasion. However, the authorities were unwilling to pursue this possibility.

6 Much of the smuggled oil was legally imported into Albania, and hence subject to customs duties and excise taxes.
} 
into the market, the pyramid schemes raised their interest rates again, to 8 percent a month. ${ }^{7}$ The outcome of the elections was also crucial. The elections were widely seen as rigged, so that local government elections scheduled for October took on a greatly increased significance. In these circumstances, the government did not want to give people any unpleasant surprises, and the tendency to ignore the growth of the pyramid schemes and hope that problems would never materialize was reinforced.

In early 1996, new pyramid schemes entered the scene, drawing in more depositors, ratcheting up interest rates, and further confusing the authorities. The informal deposit-taking market had previously been dominated by a few large companies. (For a brief description of the most important Albanian pyramid schemes, see Table 2 and Box 2.) The three largest companies of the time, VEFA, Gjallica, and Kamberi, all offered interest rates of 4-5 percent a month, increasing, as described above, to 6-10 percent in the first half of 1996; all three companies had substantial real investments and activities. In 1996 these were joined by two new schemes, Xhafferi and Populli, and one already existing but increasingly active one, Sude, which offered higher interest rates (12-19 percent a month in May 1996) and had no real investments. ${ }^{8}$ This had baleful effects. First, more deposits were drawn in. Although VEFA was the largest scheme in terms of liabilities, it only had about 85,000 depositors. Xhafferi and Populli between them attracted over one million depositors within a few months, in a country with a population of three and a half million. Second, it increased the pressure on the existing schemes to increase rates or compete in other ways. Finally, the existence of companies that were obviously pyramid schemes caused the authorities to draw a false distinction between them and the similar companies that had real investments, and to assume that the latter were solvent.

In the second half of 1996 mania took hold. In July, Kamberi raised its interest rate to 10 percent a month. In September, Populli began offering over 30 percent a month. In November, in a final spasm, Xhafferi offered to treble depositors' money in three months (a monthly equivalent rate of 44 percent) and Sude responded with an offer to double the principal in two months (a 41 percent monthly rate). By November, the face value of liabilities had reached US\$1.2 billion. Yet even these numbers fail to capture the lunacy that gripped Albania during this period. Queues formed to deposit funds with both the pure pyramid schemes and the longer established companies, and a massive number of new depositors poured in, especially to the high interest schemes. The crowd was composed not only of the poor and the gullible but also of those who

\footnotetext{
${ }^{7}$ Interest rates in the formal financial sector also rose during this period (see Figure 1). Political uncertainty and a preelection loosening of fiscal policy caused the lek to depreciate by some 15 percent during the first 5 months of the year, and underlying inflation rose from 10.6 percent to 19.1 percent a year. In response, the Bank of Albania tightened monetary policy, raising minimum interest rates on 12-month deposits from 13.25 percent to 16 percent. However, the increase in annualized interest rates offered by the pyramid scheme companies (from about 100 percent to about 150 percent) cannot be explained by these changes.

8In Xhafferi's case there was a smattering of window dressing. Xhafferi sponsored a football team in one of the most depressed towns in Albania and recruited the former captain of the 1978 World Cup-winning Argentina team to coach it. The football ground was the scene of one of the first pyramid scheme riots.
} 


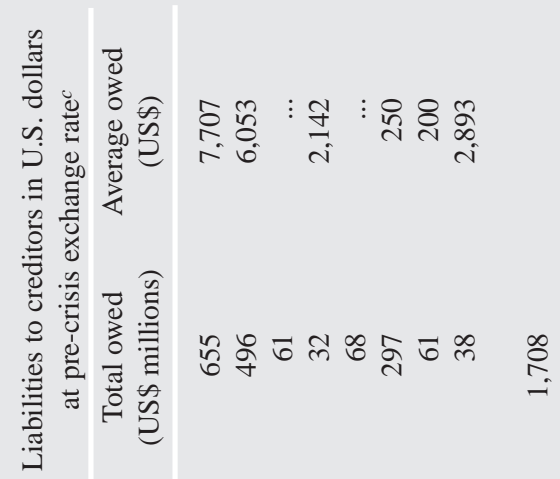

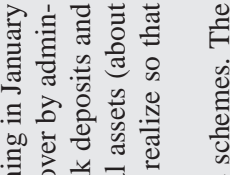

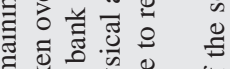

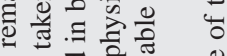
on

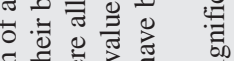

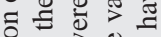

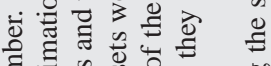
可 है

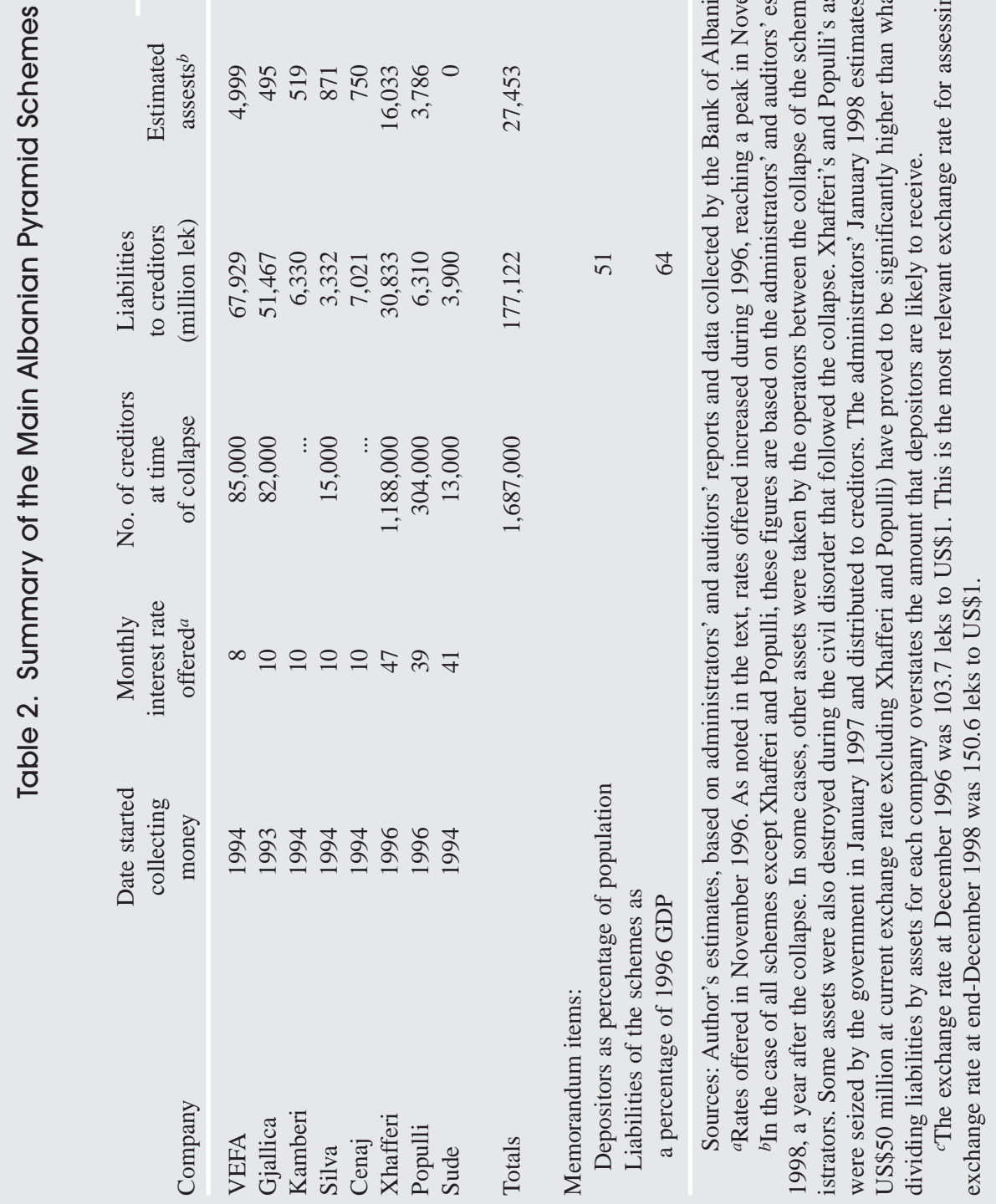




\section{Box 2. The Major Albanian Pyramid Schemes}

Altogether, 17 companies were put into administration by the authorities following the crisis of 1997. The following is a sketch of the most significant of them.

VEFA. The largest and most important of the companies, ${ }^{1}$ the auditors believe that VEFA took in at least $\$ 700$ million in deposits, and probably over US\$1 billion. When it was taken over, liabilities, excluding some US\$200 million in accrued interest, amounted to US\$250 million, while its assets were generously estimated at US\$30 million. VEFA was founded in October 1992 as a trading company but soon started taking deposits, and by late 1996 was offering an interest rate of 8 percent a month. Its president, Vehbi Alimucaj, was by most accounts attempting to build a business empire, but took a fateful decision to do so by raising cash at unsustainable rates. The company's assets included supermarkets, restaurants, a bitumen mine, a cruise ship, an entertainment complex, and a television station.

Gjallica. A huge and massively fraudulent scheme, Gjallica was started in 1991 as a currency exchange, but afterward began taking deposits. In total, US\$850 million in deposits were taken, though auditors estimate that over 80 percent of this came in during 1996, when Gjallica was offering interest rates of about 10 percent a month. Gjallica was something of an elite company, with about 170,000 investors at its peak and an average investment of almost US\$5,000. At the time of its collapse, its liabilities were US\$343 million, its assets worth US\$3 million. The owners fled to Turkey, having, according to the auditors, withdrawn at least US\$17 million during the scheme's operation. Gjallica was based in Vlore, a large city in southern Albania known as a smuggling base. Its collapse triggered the first wave of violent civil disorder.

Populli. Started as a "charitable foundation" in early 1996, but was actually a pure pyramid scheme. Populli attracted over 300,000 investors. By the end, Populli was offering to pay two times principal invested after three months. Its liabilities at the time of collapse were over US $\$ 150$ million. Much of its money was held in the state banks and was seized by the authorities. Depositors got back 60 percent of their investments.

Xhafferi. Started by Rrapush Xhafferi as a spinoff from Populli, Xhafferi quickly outstripped its rival. At the time of its collapse, liabilities were over US\$300 million. About half of this was returned to depositors from seized bank deposits. Xhafferi went for a mass market, posing as a benefactor, sponsoring a football team, and attracting over one million depositors, with an average investment of about US\$250. At the end, he offered "three times principal after three months."

Sude. Maksude Kademi started by running a lottery in the shoe factory where she worked, but then began operating a pyramid scheme. By the end, she was offering to "double your money in two months." Sude was the first scheme to fold, in November 1996, with liabilities variously estimated at US\$40-90 million, and no assets. Considering that most of the deposits paid into Sude were made in the last two months of its operations, the disappearance of the assets is suspicious. Ms. Kademi was sentenced to 3 years and 4 months in prison for conspiracy to defraud.

${ }^{1}$ Most deposits in the pyramid schemes were made in leks, though some were made in foreign currencies. In converting into dollars, for most of the schemes, an exchange rate of 150 leks to 1 U.S. dollar is used, as this was the average exchange rate in 1998, when most of the companies were finally brought under effective control. However, for Xhafferi and Populli a rate of 105 leks to 1 U.S. dollar is used, because this was the rate at the point when the Bank of Albania froze their deposits in January 1997. 
Figure 1. Albania: Interest Rates and Inflation

Bank Nominal Interest Rates

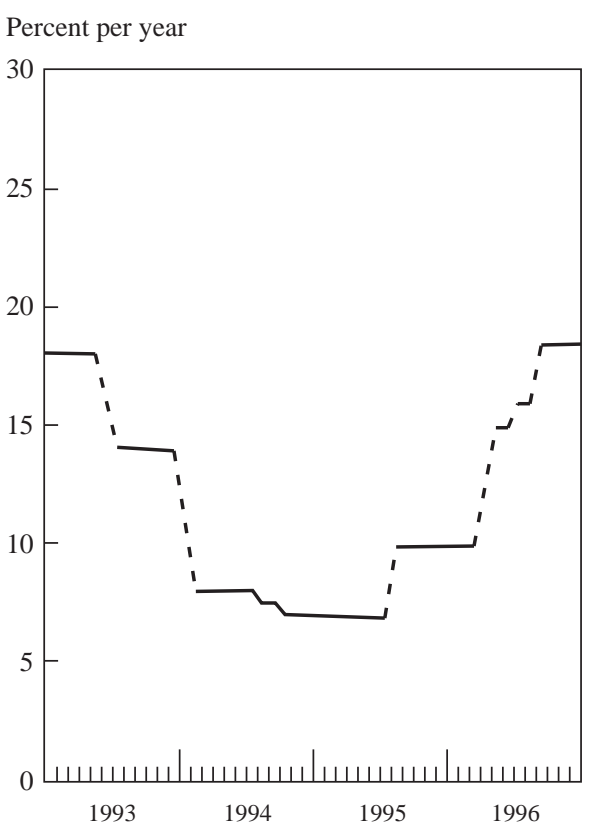

Inflation

12-month percent change

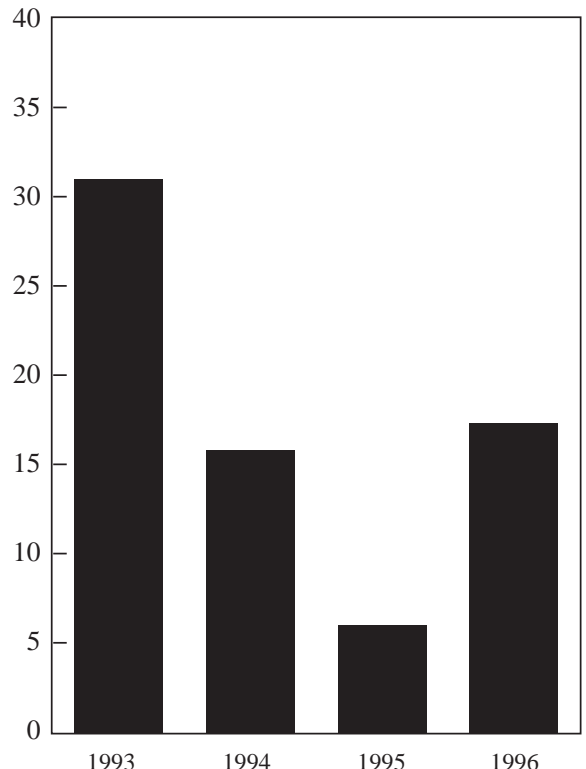

Percent per month

Informal Market Interest Rates and Inflation

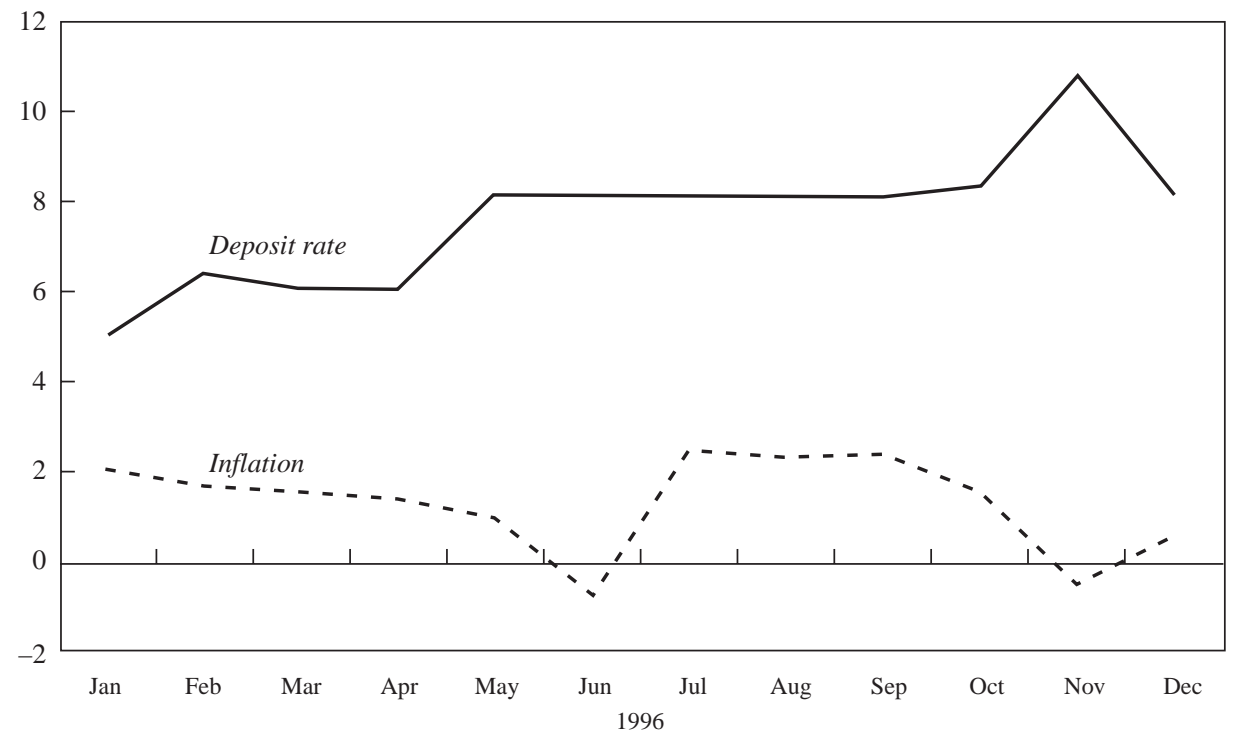

Source: National authorities. 
believed that the schemes had either government support or sources of funds derived from illegal activities which would sustain their returns, and of those who appeared to believe that "when the rest of the world are mad, we must imitate them in some measure." 9 People sold their houses and apartments to invest in the schemes; farmers sold their livestock. The mood is vividly captured by a resident who said that Tirana, in the autumn of 1996, smelled and sounded like a slaughterhouse, as farmers drove their animals to market to put the proceeds in the pyramid schemes.

Through all of this, the government was a passive observer. Although the Governor of the Bank of Albania had sent monthly letters since the beginning of the year updating the government on the interest rates being offered by the schemes, and warning of their nature, it was not until October that the Minister of Finance, returning from the IMF and World Bank annual meetings in Washington, warned the public for the first time about the risks of the schemes. Even then, government statements often compounded the problem. In particular, a false distinction that the government drew between the companies with real investments and the "pure pyramid schemes" obscured the fundamental insolvency of all of the schemes. ${ }^{10}$ When it was suggested that some of the companies might be surviving by laundering money for the Italian Mafia, the President himself came to their defense, arguing that these were legitimate and successful Albanian companies. In November, again responding to outside pressure, the government set up a committee of academics to investigate the schemes, with the main focus still being on the pure pyramid schemes. The committee never met.

The IMF and World Bank did give increasingly strident warnings about the schemes in the course of 1996, but these warnings were not heeded and may have been too late to do much good in any case. Both institutions had expressed concern as far back as December 1994 about the dangers of criminal enterprises operating in the informal market, though the concern was as much about money laundering as about pyramid schemes. However, it was not until August 1996 that a strong warning was given. It was in that month that the Bank of Albania communicated its concerns to an IMF mission visiting Tirana. Concern was also triggered by the mission's first look at the June and July monetary data, which, as discussed below, contained the first intimations of the effects of the pyramid scheme phenomenon on the banking system. The mission left a letter with the president warning him about the schemes and urging early action. In September, a World Bank mission repeated these warnings even more vigorously. However, even then, nobody had any idea of the size of the schemes. It was only in October, when the Bank of Albania found out that VEFA's deposits in the banking system were equivalent to

\footnotetext{
${ }^{9}$ The phrase was used by a banker who invested in the South Sea Bubble (see Box 3) and is quoted in Kindleberger, 1978. The similarities between the pyramid scheme mania and other financial manias are discussed below.

${ }^{10}$ One of the more bizarre features of the year was that the operators of the schemes did not themselves have a consistent name for their activities, so that many, including those with real investments, simply adopted the name "pyramid schemes" given to them by foreign observers, but stripped it of its pejorative implications. This led to quotes like a government official's reported assertion that "Our pyramid schemes are the cleanest pyramid schemes in Europe."
} 


\section{Box 3. Pyramid Schemes Old and New}

Pyramid schemes have a long and inglorious history. The Albanian schemes deserve a small place in the rogues' gallery for their size relative to the Albanian economy and for the dramatic consequences of their collapse. But for historical significance, they do not compare with the South Sea Company, which, if it was not a strictly defined pyramid scheme, had many of the features of one, and for notoriety they must defer to the operations of Charles Ponzi, whose name became synonymous with the phenomenon.

\section{The South Sea Bubble}

The South Sea Company was a pyramid scheme in two senses: the return to investors came from a rising share price fueled by money from new investors, and the rise was engineered by massive fraud on the part of its operators. There are also features-the intimate involvement of the state in the scheme and the fact that no returns were actually paid during the period of intense speculation in the shares-that make it unlike a conventional pyramid scheme. But its history (including striking parallels with the Albanian case) makes it worth examining in detail.

The company began as a legitimate scheme to redeem British government debt. In 1710, the government granted the South Sea Company trading privileges, and, in return, holders of government paper, which had not been guaranteed by parliament and which was trading at a discount, were offered the opportunity to exchange it for shares in the company. The government committed itself to pay the company interest on this debt, but at a low rate. The difference was supposed to come from the company's trading profits. In fact, apart from a brief and unsuccessful excursion into the slave trade, the company had little in the way of real business, and it is not clear whether even investors were initially attracted by its trading prospects or by its (initially sound) financial operations on behalf of the government, coupled with a belief that any company which could generate substantial cash could make a profit in the trading environment of the time.

What the company did best, and what makes it the prototype pyramid scheme, was that the rise in the share price was largely supported by the company trading its own stock. Throughout the year 1720 , the operators lent shareholders money to enable them to buy new stock on the security of their existing stock. The money was borrowed from a client bank and from the government. Investors included the cream of the English aristocracy, including the king. Initial price rises fueled speculative buying, and so long as the price kept rising everyone was content. But when people started selling, the price fell, the company was unable to pay its dividend, and bankruptcy quickly followed. And in fact the bubble was very short lived: active trading began shortly before the South Sea Bill received royal assent on April 7, 1720. By June, rivals were proliferating, so that parliament tried to protect the company by enacting the Bubble Act, authorizing prosecution of unauthorized joint stock companies. This rebounded on the South Sea Company, because many who had made speculative bargains in the companies that were being attacked could not meet their commitments without selling South Sea stock. By December 1720, the company was bankrupt, and its

US\$120 million (5 percent of GDP), that the enormity of the problem became clear. In October, in Washington, the IMF and World Bank repeated their warnings, finally producing a public warning from the Minister of Finance. Press and public reaction was mostly negative: the IMF was accused of trying to close down Albania's most successful firms. The president of VEFA, a former organizer of street cleaners, commented that the IMF was not fit to clean the streets of Tirana. Finally, in a November 19 press conference, another visiting IMF mission warned the public about the schemes and urged the government to investigate all of them. On the same day, Sude defaulted on its payments, and the collapse began. 


\section{Box 3. (concluded)}

government sponsors, many of whom had been bribed with discounted stock in the rising market, were out of office and disgraced. Parliament voted to seize the assets of those involved, including corrupt politicians. However, even with the full force of law behind the planned seizure and liquidation, it took trustees appointed by parliament over 7 years to realize some 2 million pounds in such seizures. The government also had to take back its debt and pay off the holders, though the exchange did not help those who had speculated.

\section{The Ponzi Scheme}

Charles Ponzi's scheme was also short lived. He issued his first notes for US\$800 in Boston in December 1919. By the summer of 1920 he was a millionaire. On November 1, 1920 he pleaded guilty to mail fraud. Ponzi claimed to be investing in "international reply coupons," which immigrants to the United States could send to relatives to pay postage on international mail, and which, because of currency movements during the First World War, traded at widely varying values in different countries. In principle, there were opportunities for arbitrage, except that the coupons could not be traded for cash legally, there were not enough of them, and Ponzi never bought them anyway, except a few for window dressing.

\section{Contemporary Pyramid Schemes}

One common feature of the South Sea Bubble and the Ponzi scheme was that their investors believed that their profits were derived either from special privileges conferred by the government (South Sea) or by a loophole arising from undervalued government-backed instruments (Ponzi). To some extent this was also the appeal of a contemporary scheme, MMM, which rose and fell in Russia in 1994, and which purported to be investing in privatization bonds. Others have traded on local political links, notably Caritas, the notorious Romanian pyramid scheme that was a pure pyramid but which enjoyed the support of the local mayor who was also the leader of one of the parties in the governing coalition. Indeed, it is one of the ironies of pyramid schemes, which seem at first sight to be a manifestation of the rawest form of unregulated market capitalism, that most rely on a purported association with governments. Sometimes operations that attempt innovative financial transactions rely on wholly imaginary links: one can, for example, invest in bulk purchases of international lottery tickets through a company calling itself International Monetary Funding — no relation.

\section{The Crisis of 1997}

\section{Collapse}

It took four months for the remaining pyramid schemes to collapse, bringing down with them the Democratic Party government, and plunging Albania into anarchy. The collapse of Sude shook confidence in all of the borrowing companies. People began to listen to the warnings, and the flow of new deposits ceased. In an unusual attempt to convince depositors of their soundness, the owners of VEFA, Kamberi, Silva, and Cenaj agreed to reduce interest rates to 5 percent a month. The tactic did not succeed. In January 1997, both Sude and Gjallica, one of the funds with real investments, declared bankruptcy, triggering riots, especially in the southern city of Vlore, where Gjallica was based. As the riots intensified and spread, the remaining schemes ceased payments. 
The government initially tried to limit the damage caused by the pyramid schemes and belatedly took some important measures, but still failed to control the largest companies. Most important, throughout the violence, the government stuck firmly to the principle that depositors would not be compensated for their losses from the budget. This crucial and courageous decision, which was endorsed by the opposition, made economic stabilization after the crisis much easier. The government also finally began to move against some of the companies. On January 26, 1997, it froze the bank accounts of Xhafferi and Populli, which contained an astonishing US\$250 million (10 percent of GDP). The Bank of Albania, acting on its own initiative, began to limit daily withdrawals from bank accounts to 30 million leks (then about US\$300,000) to prevent other schemes from emptying their accounts. These measures helped: the seized assets of Xhafferi and Populli amounted to about half their liabilities, and this money was returned to depositors over the ensuing months. In February, parliament passed a law banning pyramid schemes (but not defining them). However, the government was still trying to maintain the distinction between the companies with real investments and the "pure pyramid schemes," and it still did not move against the largest schemes. VEFA, for example, was allowed to continue advertising on television during the worst of the violence.

The measures taken by the government proved to be too little, too late. The government's authority, shaky since the May 1996 elections, had evaporated, and on March 8, 1997, it resigned. By this time, Albania was in chaos. The government had lost control of the more prosperous south of the country, where investments in the schemes had been highest. The army and police had mostly deserted. By midMarch armories were being looted in the south by rioters and in the north by the President's supporters; evacuation of foreign nationals and mass emigration of Albanians to Italy began. When Tirana itself fell into civil disorder the president agreed to hold new parliamentary elections by the end of June, and an all-party interim coalition government led by members of the former opposition Socialist Party was appointed.

\section{Recovery Program}

The interim government inherited a desperate situation. Some 2,000 people were killed in the violence that followed the pyramid schemes' collapse. Almost one million weapons were looted. In April, large parts of the country were still out of the government's control. Government revenue collapsed, as customs posts and tax offices were burned. By end-June the lek had depreciated against the dollar by 40 percent; inflation during the first half of the year was 28 percent. Many industries had temporarily ceased production, and trade was interrupted. Meanwhile, the major pyramid schemes continued to hang on to their assets, proclaim their solvency, and resist closure. Moreover, the political authority of the government was doubtful. Parliament continued to be dominated by the Democratic Party, and President Berisha continued to block action against the remaining pyramid scheme companies. Only in July, when new parliamentary elections gave it a decisive majority and President Berisha resigned, did a new 
government, a five-party coalition headed by Socialist Party leader Fatos Nano, have a free hand in dealing with the crisis.

Despite its handicaps, the interim government had made strong efforts to restore order and to stabilize the economy, drawing on the assistance of the international community. In April, the new government invited a multinational force led by Italy to restore order, and the situation in the capital and northern cities stabilized. In May, the government took steps to restore tax collection, with assistance from the EU, the IMF, and the World Bank. The newly elected government, with a largely unchanged economic team, continued this progress. By early September, the government had agreed with the IMF on an economic program supported by emergency assistance. Major elements included an increase in the VAT rate from $121 / 2$ to 20 percent, strict monetary control, and a resumption of structural reform, including long-overdue reforms in the banking sector. The program quickly bore fruit: output and trade began to pick up again; by end-December 1997 the lek had appreciated by 20 percent; inflation during the second half of the year fell to 11 percent; and the budget deficit was brought under control for the first time since 1995.

\section{Winding Up the Pyramid Schemes}

Dealing with the remaining pyramid schemes proved more difficult. The consensus that depositors would not be compensated for their losses from the budget held, but, on other aspects of the problem, divided political authority slowed progress throughout the period of the interim government. The new Minister of Finance, encouraged by donors and international financial institutions, quickly decided that to give depositors confidence that the pyramid schemes would be wound up in an honest and transparent way, foreign administrators should be appointed to liquidate them. However, given the inadequate legal framework, this required new legislation. ${ }^{11}$ This proved very difficult to enact. Several of the largest companies were still controlled by their operators, and there was great reluctance, especially by members of the outgoing parliament, many of whom were reported to have invested in the schemes, to move firmly against them. Nevertheless, recognizing that at least the appearance of action was necessary, parliament enacted in May 1997 a law providing for the auditing of the schemes by "a group of financial experts" to be appointed by the Council of Ministers. The law was a public relations exercise rather than a serious attempt to address the problem. It concluded with a transparent attempt to embarrass the new Minister of Finance, who was from the former opposition party, by giving him the impossible task of reporting to parliament on the outcome of the audit within three weeks.

\footnotetext{
${ }^{11}$ It would have been possible in theory to use the existing bankruptcy law to take over the pyramid scheme companies. However, this would have meant that administrators would be appointed by the courts, which were notoriously corrupt (a survey funded by the World Bank in 1998 found that the judiciary was regarded as the second most corrupt institution in Albania, after the customs service) and open to influence by the pyramid scheme owners.
} 


\section{New Law Allowing the Appointment of Administrators}

With parliament having dissolved for elections to be held on June 29, 1997, the interim government was left with an unworkable law and the companies still being controlled (and gradually drained) by their operators. In response, the government proposed action by presidential decree, and sought the advice of the IMF and World Bank. Meeting in Rome on June 9-10, 1997, representatives of the government and the president, assisted by the IMF and the World Bank, drafted a new decree. This was approved by the government, but President Berisha, upon signing it, reinserted the clause in the May law requiring the Minister of Finance to report to parliament by the original (now already passed) deadline of end-May. Since this could have led to the Minister being jailed, the government rejected it. The substance of the draft decree (without the offending clause) was finally approved as a law by the newly elected parliament in July 1997, and signed by Berisha's successor, President Mejdani.

The main elements of the new law were the following:

- all pyramid schemes were to be made subject to control by administrators;

- the administrators were required to be "a company qualified and reliable in the field," which in practice meant that they should come from a major international accounting firm with experience in insolvency work; there should also be auditors from international accounting companies;

- the administrators were required to report regularly to the government, but were otherwise to be completely independent in their work;

- the administrators were given very wide powers, including the power to carry on the companies' businesses, pay their debts, sell their assets, and decide whether to retain staff or managers; the power to seize the assets of named individuals connected with the schemes; and discretion to hire experts and trace assets abroad;

- there were criminal penalties for failure to cooperate with the administrators; and

- the administrators were given the explicit power to stop the schemes from taking further deposits or engage in new borrowing.

\section{Problems of Administration}

The costs of hiring foreign administrators were borne by the government, which drew on grants and concessional loans from donors and the World Bank in doing so. The continued involvement of the World Bank and the IMF also provided opportunities for the donors to monitor the administrators' proposals and work. This proved useful, since the problems facing the administrators were considerable. The new law had been drafted (as a decree) in June, but because President Berisha refused to sign the decree there was a delay of a month until the newly elected parliament passed the law. There was a further delay while foreign administrators were appointed, and even after this the pyramid scheme owners did not give up, resisting by both legal means (challenging the legislation in the courts) and less savory ones (threats of violence 
against the administrators). ${ }^{12}$ As a result, the administrators were only able to take up their duties in November 1997, by which time the operators had significantly reduced the liquid assets of the schemes. Moreover, it took some further months to dislodge the operators completely, partly because the administrators needed the cooperation of at least some of them in finding the assets of the companies, and partly because the employees of the companies (including a virtual private army of security guards in one) remained loyal to the operators, not the administrators. Only in March 1998 was control of all of the companies finally established. The owners who had not fled were jailed, and the administrators began the difficult task of preparing the remaining assets for sale.

There were also clashes between the government and the foreign administrators, in part reflecting differences of view about how firm to be with the operators (the government generally taking the tougher line) and in part because of a culture clash between the two. Foreign administrators used to reliable law enforcement were frustrated by uncooperative courts and banks and felt vulnerable to physical intimidation of their employees by the pyramid scheme operators in a still-precarious security environment. For their part, underpaid and overworked government officials, some of whom had themselves shown great personal courage in taking on the pyramid scheme operators, thought the administrators were too slow in tackling their work and unresponsive to the government's needs and constraints. The intercession of the World Bank and the IMF was, on more than one occasion, necessary to keep the two sides working together toward the same goal.

Finally, while the foreign administrators and auditors have done an excellent job in rendering the operations of the schemes transparent, the process of asset recovery has been disappointing. The losses during the period when the operators retained control of the schemes, the difficulty in establishing clear title to some of the schemes' assets, and the further difficulty in selling those assets, especially businesses, in a depressed economy with continuing security problems, have resulted in very limited asset recoveries so far. Indeed, the most successful exercise in asset recovery was the government's own seizure of the financial assets of two pyramid schemes in January 1997. Taking control of and disposing of real assets has proved much more difficult.

\section{Economic Effects of the Pyramid Scheme Phenomenon}

The Albanian pyramid schemes were highly unusual, in that they were of a magnitude sufficient to have effects on the whole economy. Nevertheless, considering that the face value of their liabilities was so large — about half of 1996 GDP - the direct effects of their rise and fall appear to have been limited. They are also extremely difficult to identify, in part because of the limitations of data on the real

\footnotetext{
12The government's lack of confidence in the courts turned out to be well justified. In November 1997, the Constitutional Court, whose members had all been appointed by the previous administration, declared the law under which foreign administrators were appointed an unconstitutional infringement of private property rights. Parliament responded by passing the law again as a constitutional amendment.
} 
economy in Albania and in part because their collapse had profound political and social effects, in particular the outbreak of civil disorder, which, in turn, had a powerful effect on the economy. ${ }^{13}$

Outbreaks of pyramid schemes on the Albanian scale have fortunately been sufficiently rare that little or no work has been done on predicting their macroeconomic effects. Perhaps the closest analogy is other kinds of bubbles: in the stock market or in specific assets. In these cases, one would expect the main effects on the macroeconomic indicators to be through changes in perceived wealth. As the bubble (or the pyramid scheme) expands, people believe themselves to be better off than they actually are. Their demand for goods and for money therefore increases, and in the external accounts the current account can be expected to deteriorate. The increased demand for goods should produce some increase in either output, or inflation, or both. Also, to the extent that the bubble or scheme attracts money from outside the country, there would be an expansion of the money supply and capital inflows that may be sufficient to fund the deterioration of the current account deficit. After the bubble bursts or the scheme collapses, perceived wealth falls dramatically (and actual wealth may also have fallen, if it has been spent on consumption goods or if the scheme's operators have succeeded in stealing the money and taking it abroad). Therefore, one would expect demand for goods and money to fall, output and/or inflation to fall somewhat, and the current account to improve.

Some of these effects were observed in Albania, but others were not, and to the extent that they can be identified during the period of the pyramid scheme mania, the effects directly attributable to the schemes appear to have been limited and short lived. The picture is confused by a significant loosening of the fiscal stance in 1996, which contributed to rising inflation. Inflation rose sharply in 1996, from about 6 percent during 1995 to about 17 percent, and the current account of the balance of payments excluding official transfers deteriorated by about 2 percent of GDP, to 9.1 percent of GDP (Table 1). The deterioration was fueled by a 35 percent increase in imports but dampened by a significant increase in private transfers, some of which were paid into the pyramid schemes. The effects of the pyramid scheme phenomenon show up most clearly in the import figures, which show a consumption boom (albeit a short-lived one) late in 1996. The boom may have had some effect on inflation, but probably not a substantial one: the expansion of broad money resulting from an increased budget deficit (the result of a preelection wage increase and a falloff in revenue collection) was significantly greater than inflation during the year, implying a fall in velocity of circulation. The effects of the pyramid schemes on output are also unclear. During 1996, the peak year for pyramid scheme activity, output grew by about 9 percent. This was a growth rate similar to each of the previous three years, but the schemes may have helped sustain a growth rate that would have otherwise fallen. Output

\footnotetext{
${ }^{13}$ As of 1998, there were no national accounts data collected in Albania. GDP estimates are based on firm data on agricultural production and the production of state enterprises and very partial data on the growing private industrial and service sector. Moreover, the government's figures for the election year of 1996 were particularly suspect, and collection of some data for 1997 was interrupted by the civil disorder.
} 
figures in Albania are in any case highly unreliable, and anecdotal evidence points to the schemes having had mixed effects. For example, employers reported difficulty in attracting workers during late 1996, as many people preferred to live off the interest from the pyramid schemes. On the other hand, the slaughter of livestock by farmers eager to invest in the schemes had the effect of increasing agricultural output in 1996 (while depressing it in future years as the capital stock diminished). The schemes' own investments appear to have added little to output, as they were mostly window dressing.

The growth of the pyramid schemes did produce major changes in the monetary indicators, especially in the second half of the 1996, but there was little impact on the banks or on the broader economy arising from these changes. Table 3 reveals a number of striking changes in the monetary indicators, but also some interesting continuities. Beginning in June 1996, there was a rapid expansion of broad money fueled entirely by an increase in deposits. Moreover, almost all of this increase came from lek deposits of private sector companies (about an eightfold increase between May and December 1996) and foreign currency deposits of private sector companies (about a fourfold increase over the same period), giving a total increase in private sector deposits of 37.3 billion leks, or over 50 percent in seven months. Almost all of the new deposits were made by the pyramid scheme companies themselves. Thus, in the period to end-September, VEFA's deposits rose to some 15 billion leks (about US\$150 million at current exchange rates). By the end of the year VEFA had run down its deposits somewhat, but there were massive new deposits from Xhafferi and Populli, amounting to 27 billion leks (US\$258 million at end-1996 exchange rates). This behavior produced a major shift in the currency deposit ratio, a fall from 68 percent in June 1996 to 43 percent in November. However, it is revealing that deposits from other groups changed very little. There was a fall of about 4 billion leks (a little over 12 percent) in foreign currency time deposits of households in the last three months of the year, presumably reflecting withdrawals of deposits to invest in the schemes, but this accounts for only about 10 percent of the increase in deposits of private sector companies. The implication is that almost all of the deposits in the pyramid schemes came either from abroad (from Albanian emigrants or migrant workers) or from foreign currency cash held by residents.

It may seem remarkable that the pyramid scheme companies should have deposited their funds in state banks that were paying only a fraction of what the companies had to pay depositors, and where they were vulnerable to seizure by the government. The decision to do so appears to have been in part caused by the absence of alternatives in the short term, and in part a reflection of the companies' confidence that the government would not interfere with them. Indeed, except in the cases of Xhafferi and Populli, two of the least politically connected schemes, this confidence turned out to be largely justified.

Finally, it should be noted that while the increase in total deposits was very large, the banks and the economy were largely insulated from the effects of the increase. The increase in deposits did not fuel further monetary expansion through the money multiplier, because most of the deposits were in state-owned commercial banks, whose lending was subject to strict limits. The banks therefore initially 


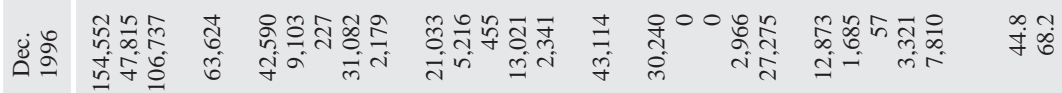

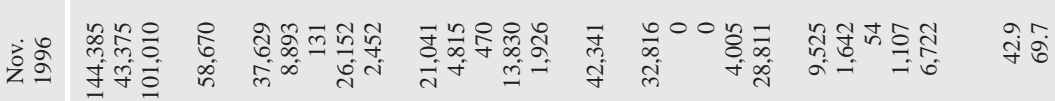

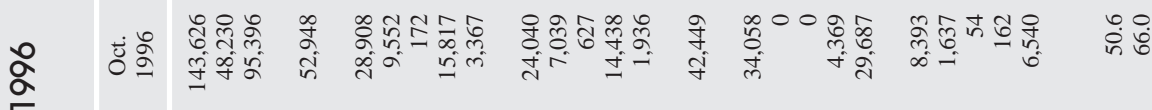

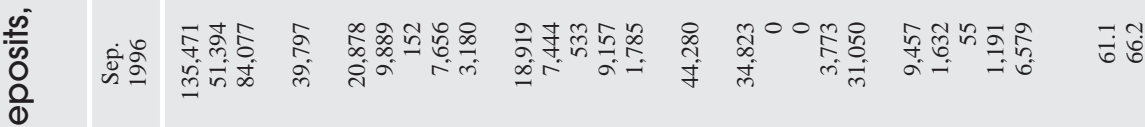

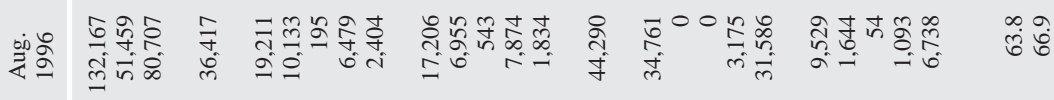

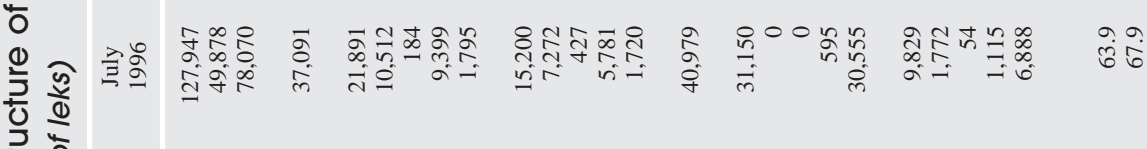

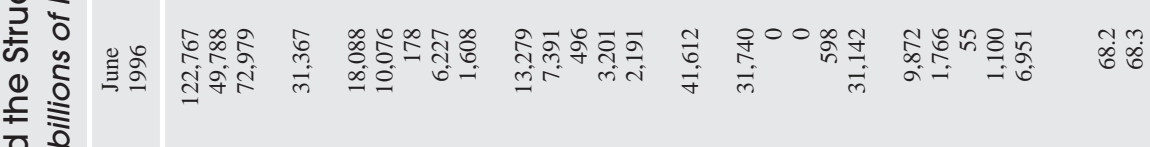

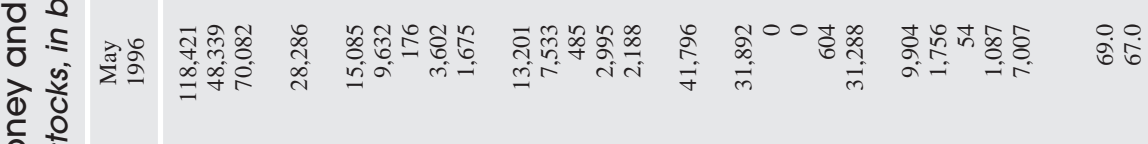

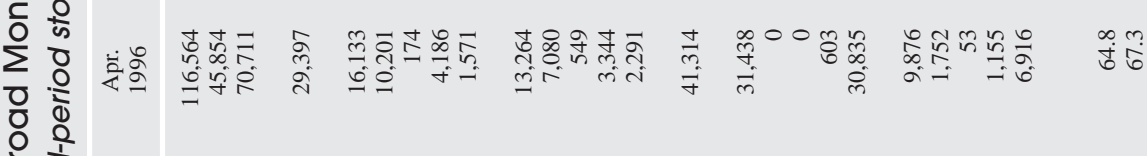

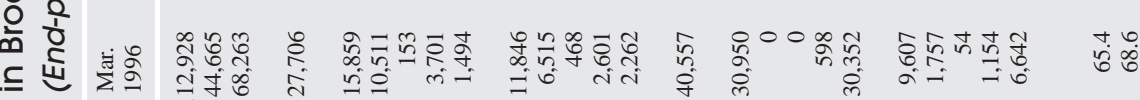

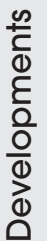

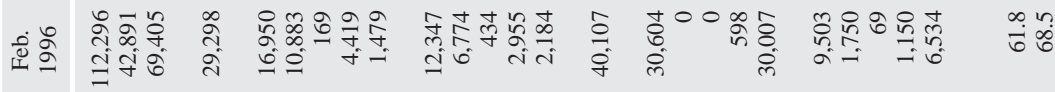

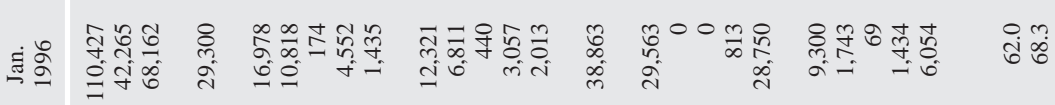

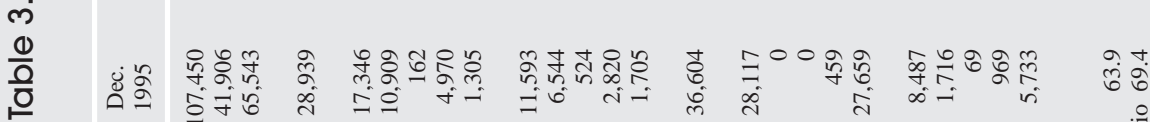

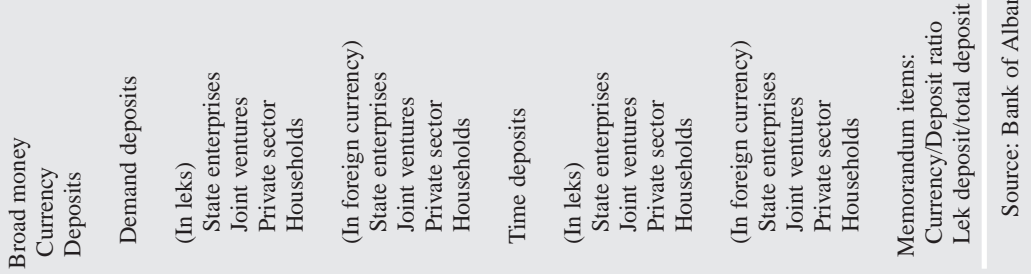


accumulated excess reserves, and then, with the agreement of the Bank of Albania, invested almost all of the new deposits in treasury bills, some purchased from the government, some bought from the Bank of Albania in the secondary market. Thus, the government was able to finance its deficit courtesy of the pyramid schemes, but there was virtually no increase in private sector credit arising from the increase in deposits.

The effects on the economy in 1997 of the pyramid scheme collapse are even more difficult to calculate, because the collapse triggered widespread civil disorder. Output is estimated to have fallen by 7 percent in 1997, with a larger fall having occurred in the first half of the year and some recovery in output thereafter. However, it is impossible to separate out the supply-side effects of the civil disorder from the demand-side effects from the loss of savings in the pyramid schemes. Similarly, the increase in inflation to over 40 percent in 1997 can be attributed almost entirely to the depreciation in the exchange rate and to the sharp rise in the fiscal deficit caused by the collapse of revenue during the civil disorder. Recorded imports fell by over 25 percent, an unwinding of the import boom of the year before, but also a reflection of disruptions in trade and almost certainly increased smuggling during the crisis. Capital inflows declined, but did not turn into net outflows (nonresident depositors in the pyramid schemes could not, after all, get their money out). Actually, it is striking how limited an effect on economic variables even the combined effect of a major loss of private savings (through the pyramid scheme collapse) and a major disruption of production (due to the civil disorder) appear to have had in 1997.

In 1997, as in the previous year, there were dramatic changes in the monetary indicators, which had only a limited impact on the banks or on the economy. As shown in Table 4, there was a massive fall in private sector deposits in the course of 1997. This reflects in part the seizure and gradual distribution of the financial assets of Xhafferi and Populli and in part a gradual rundown of assets of other schemes by their owners prior to the taking over of those companies by administrators. ${ }^{14}$ The extent to which these assets were used to pay off favored depositors or cover running costs, or simply appropriated by the operators, is still subject to investigation. ${ }^{15}$ In the period through July 1997 refunded depositors seem to have mostly held cash, as reflected by a near doubling of the currency deposit ratio. However, later in the year this trend was reversed, as individuals increased time deposits held in lek. This phenomenon can be attributed partly to the high real interest rates being offered by the banks at this time: during the second half of 1997 prices only rose by 11 percent (annualized rate of 23 percent), while the (annualized) interest rate on three-month

\footnotetext{
${ }^{14}$ The anomalous figures for January 1997 in Table 4 reflect a temporary accounting treatment of the asset seizure and should be ignored.

${ }^{15}$ There were certainly some cases of outright theft, and many more of fraud, especially withdrawals of funds to purchase assets at vastly inflated prices from related parties. It is not clear to what extent these could have been prevented if the authorities had seized the financial assets of the other companies at the same time as Xhafferi and Populli. However, it appears that the limit on daily withdrawals was not an effective barrier. It was set at a relatively high level (30 million lek, or about US $\$ 300,000$ at the time the limit was imposed) and was applied to individual bank accounts rather than companies. Many companies had numerous bank accounts: VEFA, for example, had over 80 accounts.
} 


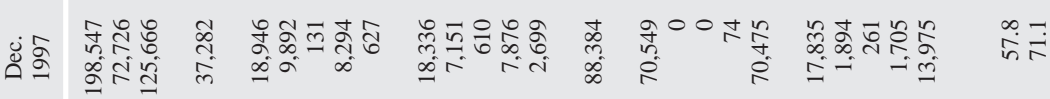

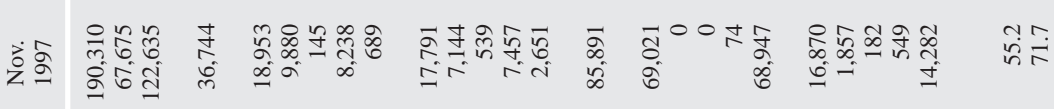

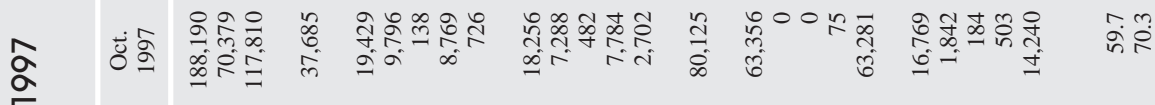

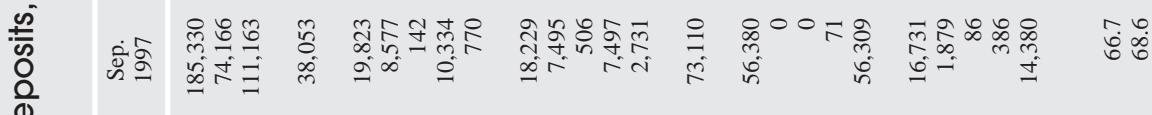
(

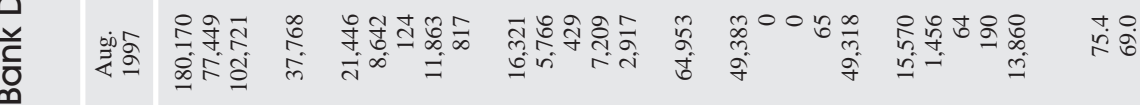

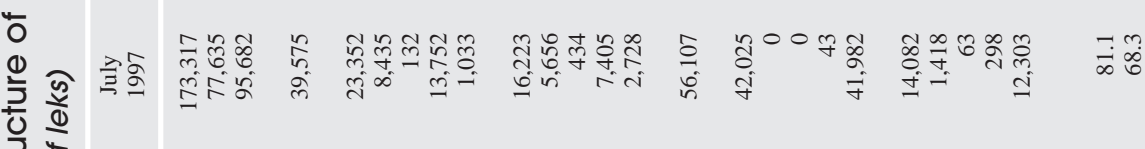

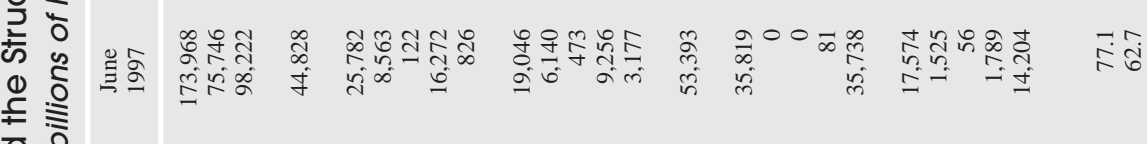

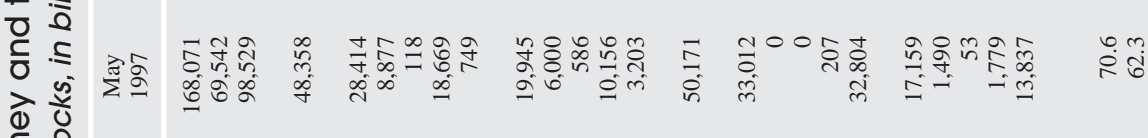

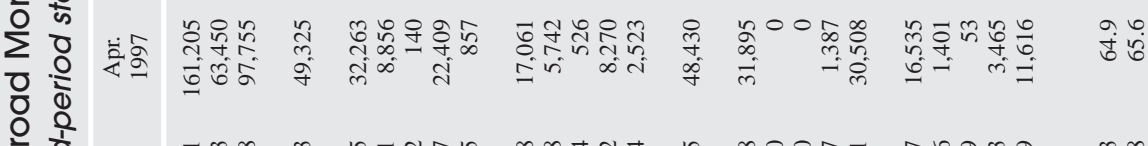

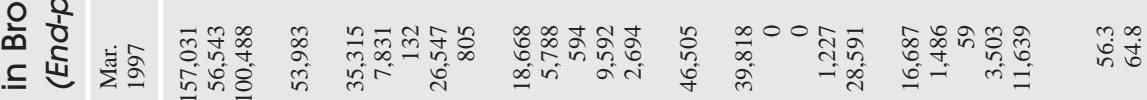

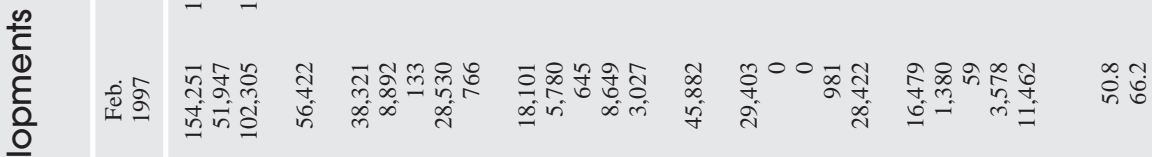

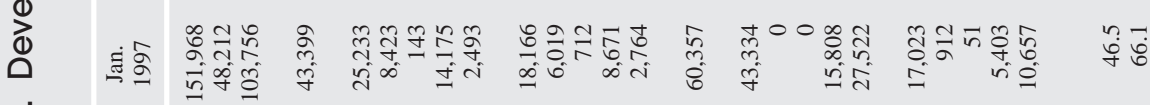

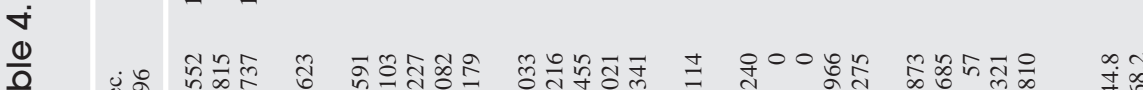
ob बूँ

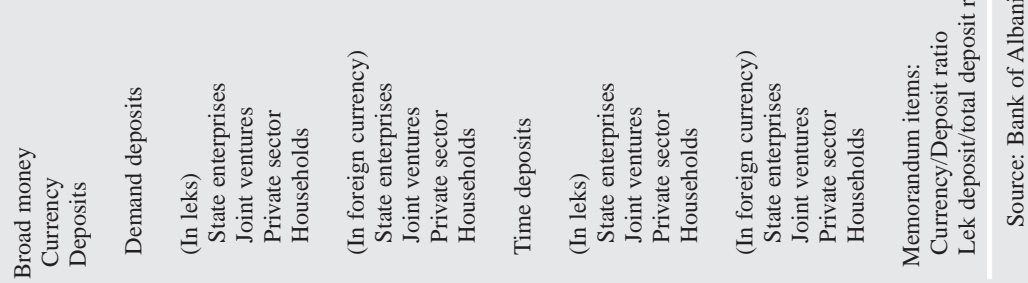


deposits was well over 30 percent for most of this period. It also seemed to reflect some increased confidence in the banks. Through all of these gyrations, the banks' liquidity position remained adequate and private sector credit increased only modestly. The effects of the changes in the currency deposit ratio were mostly absorbed by Bank of Albania purchases and then sales of treasury bills, and the real economy remained unaffected.

The long-term effects of the pyramid scheme phenomenon are still unclear, but on the evidence so far they too will be limited. Output in 1998 is estimated to have increased by about 8 percent, with an increase in agricultural output due to a good harvest offsetting disappointing investment. Investors were discouraged by domestic and external security concerns (high crime and political instability, and heightened tension in neighboring Kosovo). Inflation and the budget deficit both fell sharply in 1998. Structural reform of the banking sector is under way. One of the three state-owned banks has been closed, and another has been privatized. A new Bank of Albania Law and Banking Law, both drafted with IMF assistance, were approved, giving the Bank of Albania specific powers to prevent the occurrence of banking business by nonlicensed financial institutions. The sale by the administrators of the remaining assets of the pyramid scheme companies began in mid-1998, and sales continued in 1999. The government is still distributing the proceeds of the sales to depositors. The operators of the schemes are either in jail or out of the country.

The apparently limited effects may be an indication of the remarkable resilience of the Albanian economy, but the government's avoidance of a bailout of pyramid scheme depositors and its subsequent adjustment efforts have also been important. Albania has, since the beginning of transition, had extremely flexible prices and wages, and the fact that the government was able to cut real public sector wages substantially in 1997 (by leaving nominal wages unchanged), and that the economy was able to absorb a substantial nominal and real appreciation of the exchange rate from the heavily depreciated levels of mid-1997 without apparent competitiveness problems allowed the authorities to reduce inflation quickly after the inflationary burst in early 1997 and to prevent inflationary expectations from becoming entrenched. The new government's willingness to tackle the budget deficit and to embark on long-overdue structural measures was also crucial. Finally, the political consensus that there should be no bailout of depositors from the budget prevented major fiscal costs and moral hazard problems. It appears that no new pyramid schemes have emerged in Albania since the crisis, something that might appear unsurprising but has not always been the case in other transition economies where large pyramid schemes have flourished. To a large extent, this must be due to the political and public consensus that the burden of the losses should be borne by depositors, not taxpayers.

The Albanian experience does also suggest, however, that the macroeconomic effects of even very large pyramid schemes are likely to be quite limited. At the very least, the events of 1996 and 1997 produced dramatic shifts in the perceived wealth of individuals in the economy, but the effect of these shifts on demand is not at all clear. The strongest data are on imports, which increased in 1996 and fell back in 1997. On the monetary side, the rise of the pyramid schemes certainly did not 
produce an increase in velocity and prices, which might have been expected from the increase in perceived wealth. Elsewhere, the poor quality of the data calls for caution in drawing conclusions, but there does not appear to have been an increase in prices of other assets, for example, property (with the exception of the few properties that the pyramid scheme companies actually bought themselves at inflated prices). Possibly the main effects were on asset distribution. A few thousand people got richer, some of them much richer; many more got poorer, some of them much poorer, but on aggregate the real wealth loss to the economy was very limited.

\section{Lessons for the Future}

\section{Preventing Pyramid Schemes}

The pyramid schemes were not a product of circumstances unique to Albania. It is tempting to ascribe the kind of mania that gripped Albania in 1996 to peculiar Albanian circumstances, and to believe that it could not have happened in a more developed economy. The isolation of Albania until recently and the population's unfamiliarity with market institutions seem to reinforce this argument. But it does not hold water. Pyramid schemes have been especially prevalent in transition economies in recent years (MMM in Russia, Caritas in Romania, and smaller schemes in Bulgaria and the Czech Republic have come to light) but they also exist in industrial countries. If they rarely come to public attention in industrial countries it is probably because there are more people in these countries prepared to point out the difference between a credible and an incredible rate of return, and because better law enforcement prevents them from reaching a newsworthy size. And some of the other conditions that led to the rise of the pyramid schemes - an inadequate banking system, an unclear legal system, poor governance-are all too common in other parts of the world. It has also been suggested that the Albanian population, poor and conscious of the wealth of neighboring countries like Italy, were more than usually susceptible to the promises of the pyramid scheme operators. Again, there may be a little truth in this, but it is worth remembering that most of the British aristocracy, including the then Master of the Royal Mint, Sir Isaac Newton, fell for the South Sea Bubble.

There are steps that governments can take to make the growth of pyramid schemes less likely. The poor performance of the formal banks in Albania, and the failure of the government to tackle this issue in the years since transition began, played a major role in getting the schemes started and in concealing their damaging nature. Ambiguities in the legal framework and the absence of a clear line of responsibility for dealing with the problem delayed the necessary response in 1996 and hampered the takeover and liquidation of the companies in 1997. Finally, poor governance lay at the heart of the pyramid scheme phenomenon. There were corrupt relationships between the companies' operators and the highest levels of the Albanian government, and these relationships both prevented government agencies from taking action against the companies and disguised from investors how insecure the companies were. There are plenty of other reasons for governments to undertake 
bank reform, to enact good legislation, and to improve governance. But the Albanian experience is a salutary reminder of what can happen when all of these things slip.

Authorities should supervise closely both formal and informal financial markets. Supervision of the informal credit market in Albania was nonexistent, and since the pyramid schemes were for some time viewed as part of that market they too went unsupervised. The Bank of Albania did began to take notice at the end of 1995, at about the time that the most rapid growth of the schemes began. But again there was no institution that had clear authority to intervene. Even when the effects of the pyramid schemes began to show up in the monetary statistics, the scale of their activities was not clear to the authorities. Here the lapse was in supervision of the formal banking system. By September 1996, VEFA's deposits accounted for over one-third of all demand deposits. Such a rise in the banks' liabilities to a single customer should not have gone unnoticed. Moreover, given the rapid growth of the schemes, and the delays in obtaining data, it is not enough to rely on aggregate monetary data to sound the alarm bell about extraordinary developments in the economy.

The international financial institutions too can draw lessons from the pyramid scheme phenomenon, though their capacity to influence events is limited. It is arguable that the IMF and World Bank should have seen the problem in Albania coming earlier, and warned the authorities more sternly. However, it is not the job of the IMF and World Bank to supervise the activities of individual companies, especially when they are suspected of having criminal links. As for warnings, the IMF and World Bank were consistent in their warnings as soon as the problem became apparent, despite the skepticism of the authorities. But the effectiveness of these warnings was hampered by the absence of conditionality: disbursements from both the IMF and World Bank were already suspended because of macroeconomic slippages. Moreover, it is difficult, and could be reckless, for international institutions to say publicly that financial institutions are insolvent, if they cannot be certain about this. Whether they are insolvent or not, panic could ensue, and this could consume solvent companies as well as fraudulent ones. Finally, warnings may not be heeded: public warnings from the Minister of Finance in October were not sufficient to stop the final rush into the pyramid schemes the following month. Indeed, the experience in manias throughout history has been that warnings are often overwhelmed by enthusiasm. However, following the Albanian experience, the IMF and World Bank should be aware of the possibilities of pyramid schemes emerging when the conditions for their growth are present, and should be on the lookout for such schemes.

\section{Dealing with Pyramid Schemes}

The Albanian authorities did a reasonably good job in dealing with the pyramid schemes once they were identified. Undoubtedly the two best things that they did were to refuse a costly bailout from the budget and to freeze the assets in the banking system of the two companies with the most depositors. The latter move, in particular, saved the latest depositors, who usually suffer most, about half of their money. It would have been better if the authorities had frozen the bank accounts of the other 
companies too. It appears that a great deal of money was looted from these even after their nature was quite clear. In general, the authorities were right to take a firm hand with the operators of the schemes, and should have taken a firmer hand earlier. That they failed to do so was in part due to the weakness of the governing institutions in Albania, and in part due to the perceived need to secure the cooperation of the operators in identifying and recovering assets. There was also a certain delicacy in dealing with the depositors of the companies, many of whom had a naive faith that their deposits could be restored if the operators were allowed time to recoup their losses.

International assistance was also very important in dealing with the pyramid schemes. In a thoroughly compromised political environment, it was very helpful for the government to be able to call in international accounting firms of impeccable reputation to administer, audit, and liquidate the pyramid scheme companies, and to have this work coordinated by the World Bank and the IMF and financed by donors. It was also helpful to the authorities to be able to cite the approval and participation of the IMF and the World Bank for the drafting of the legislation to wind up the companies, and to have the steps in the winding-up process supported by IMF conditionality.

The winding-up experience contains some useful and encouraging lessons for authorities of other countries where pyramid schemes become a problem, but there are some more discouraging aspects to the experience. In particular, identifying and liquidating the pyramid schemes' assets took a great deal of time and money, and asset recovery has been very limited. To some extent this may have been due to the inadequacy of the legal framework and to delays in the takeover, but the historical experience (for example, the seven years needed to realize the assets of those implicated in the South Sea Bubble) and experience with other complicated bankruptcies suggests that the winding-up process was always likely to have been a long one. For governments, there is perhaps one silver lining to this dark cloud. The violent outburst of public protest in Albania came at a time when depositors had been regularly receiving payments that suddenly stopped. By the end of 1998, most depositors had not received a penny from the schemes for two years. They had learned to manage without, and to expect little. After enough time, even ten cents on the dollar looks good.

A final depressing note is that pyramid schemes and related financial scams are not likely to go away any time soon, and that people are likely to continue to fall for them regularly. In industrial countries, the Internet abounds with plausible-sounding schemes that are designed to attract the greedy and the gullible. In developing countries the fraud may be more public, the government more likely to be involved, and the scale larger. Honest government and central bank officials as well as international financial institutions will need to be vigilant in identifying and crushing the frauds. But there will always be a demand for offers that are too good to be true.

\section{Aftermath: The Social Costs of the Pyramid Schemes}

Albania now seems to have put the pyramid scheme crisis largely behind itself. Other problems - political conflict in Albania, corruption in the public sector, the events in Kosovo-have succeeded the pyramid schemes as the main concerns of the public. Although the process of returning money from the realized assets of the 
schemes is still not complete, and it now appears that the assets of the schemes will be sufficient to cover less than 10 percent of their nominal liabilities, there have been few complaints or public protests. When the operator of the largest scheme was finally jailed, the event was reported only on page 5 of the leading English-language newspaper in Albania.

Meanwhile, parliament has passed legislation designed to prevent a recurrence of the pyramid scheme phenomenon. In particular, a revised Banking System Law (drafted with assistance from the IMF and designed to prevent illegal activities and ensure that only financial institutions can take deposits) was approved by parliament in June 1998, amendments to the Money Laundering Law have been prepared by the Bank of Albania, and the enforcement of the Companies Law and other commercial laws is being improved. The authorities have also finally taken action to address the weaknesses of the formal financial system. Of the three state-owned banks that dominated the formal banking system in 1996, one, the Rural Commercial Bank, has been put into liquidation; another, the National Commercial Bank, has been privatized; and the third and largest, the Savings Bank, is working under a governance contract with the assistance of foreign advisors.

However, scars remain; the social effects of the Albanian pyramid scheme phenomenon have been considerable and are still not known fully. In the events triggered by their collapse, over 2,000 lives were lost. Thousands more people were impoverished either by their unwise investments in the schemes or by the destruction of their property in the ensuing violence. A government, albeit one of dubious legitimacy, was overthrown. The arms looted during the crisis have been used in armed robberies in Albania and provided a ready source of weapons to Albanian separatists in neighboring Kosovo. Less tangible, but also significant, are the effects on confidence in Albania. Before the crisis, Albania was a strikingly confident place: poor, beset already by serious problems of governance and growing economic problems, but also conscious and proud of having made enormous strides since the overthrow of Communism. For some years after the crisis Albania was a much more subdued place. Confidence in the institutions of government was low, crime and corruption imposed on most people's lives, and there was an air of grimness and insecurity even in the capital. The resilience of the Albanian people is considerable, and it has been more severely tested in the past. But the pyramid scheme phenomenon was a sobering setback for Albania, a powerful reminder of the social costs of unchecked criminality.

\section{REFERENCES}

Blejer, Mario, and others, 1992, Albania: From Isolation Toward Reform, IMF Occasional Paper No. 98 (Washington: International Monetary Fund).

Davies, Norman, 1996, Europe: A History (Oxford: Oxford University Press).

Kindleberger, Charles, 1978, Manias, Panics and Crowds: A History of Financial Crises (New York: Basic Books).

Muço, Marta, and Drini Salko, 1996, "Some Issues on the Development of the Informal Financial Sector in Albania" (unpublished; Albanian Center for Economic Research). 